\title{
MICROBIOLOGICAL STATUS OF FARMS AND BALADI HENS' EGGS
}

\author{
O.A. SADEK ${ }^{1}$; M.F. HUSSEIN ${ }^{1}$ and S.M. EL BERBAWY ${ }^{2}$ \\ ${ }^{1}$ Food Hygiene Department, Animal Health Research Institute, Assiut Lab. \\ ${ }^{2}$ Bacteriology Department, Animal Health Research Institute, Assiut Lab.
}

Received: 16 December 2015; Accepted 10 January 2016

\begin{abstract}
This study was done to determine the microbiological status of farms and baladi hens' eggs and isolation of some pathogens of public health hazard. A total of 300 farms and baladi eggs samples (150 eggs of each) and every five eggs from each sample were represented as one egg pooled sample $(\mathrm{N}=60$ pools from farms and baladi hens' eggs representing 30 pools for each) were microbiologically examined. The incidences of aerobic bacteria, Enterococci, coliforms, faecal coliforms, E. coli and yeats and molds in farms hens' eggs shell were 90, 36.7, 10, 6.7, 6.7 and 63.3\%, respectively; while, for baladi hens' eggs shell, the incidences were 100, 80, 86.7, 73.3, 53.3 and $76.7 \%$, respectively. In farms hens' eggs content, the incidences of aerobic bacteria, Enterococci, coliforms, faecal coliforms, E. coli and yeasts and molds were 36.7, 13.3, 0, 0, 0 and 26.7\%, respectively; while, for baladi hens' eggs shell, the incidences were 80, 10, 20, 10, 6.7 and 36.7, respectively. For pathogenic microorganisms, the incidences of Staphylococcus aureus in farms and baladi hens' eggs shell were 33.3 and $40 \%$, respectively; while, for egg content, the incidences were 10 and 13.3\%, respectively. Coagulase negative Staphylococci (CNS) were isolated from farms and baladi hens' eggs shell in incidences of 3.3 and $46.7 \%$, respectively; while, in eggs content, the incidences were 13.3 and $43.3 \%$, respectively. Listeria monocytogenes was isolated only from baladi hens' eggs shell in an incidence of 3.3\%. Salmonella spp. couldn't be isolated from the shell and content from both types of eggs in this study. The public heath significance and hygienic control measures were discussed in this study.
\end{abstract}

Key words: Farms eggs, Baladi eggs, Staphylococcus aureus, Listeria monocytogenes, Salmonella

\section{INTRODUCTION}

Eggs are one of the few foods that are used excessively throughout the world; thus egg industry is an important segment of the world food industry. Eggs are an important part of human diet since the dawn of recorded history. Recently, eggs have been an important commodity in international trade. Moreover, eggs provide unique well balanced nutrients for persons of all ages. Their high nutrient content, low caloric value and ease of digestibility make eggs valuable in many therapeutic diets for adults (Heranz et al., 2007; Ebubekir et al., 2008).

Corresponding author: Dr. O.A. SADEK E-mail address: onsi_2000@yahoo.com Present address: Food Hygiene Department, Animal Health Research Institute, Assiut Provincial Lab.
Freshly laid eggs are generally devoid of organisms. However, following exposure to environmental conditions (for example, soil, dust and dirty nesting materials), eggs become contaminated with different types of microorganisms (Ellen et al., 2000). Furthermore, these microorganisms may contaminate the egg contents either by penetration or withdrawal through pores of the shells (Schoeni et al., 1995), and also through the transovarian route (Bruce and Drysdale, 1994). Some other factors such as environmental temperature and humidity influence the bacterial penetration and thus, enhance the infection and spoilage (Theron et al., 2003).

Food-borne diseases caused by microorganisms are a large and growing public health problem. Contamination of eggs and egg products with microorganisms can affect egg quality, which may lead to spoilage and pathogen transmission. This may induce cases of food-borne infection or intoxication to consumers, which constitute public health hazards. 
Several pathogenic microorganisms have been isolated from the surface of egg shells and contents. Among them, Listeria monocytogenes, Yersinia enterocolitica, Escherichia coli, Salmonella and Campylobacter were detected (Adesiyun et al., 2005).

Owing to the continuous consumers' demand for fresh eggs, and egg products, it is extremely necessary, not only to increase egg production, but also to safeguard consumers against health hazards. Therefore, the aim of this study is to evaluate the microbial status of edible hen's eggs and also, trail to isolate some pathogens causing food-borne infection and intoxication to the consumers.

\section{MATERIALS AND METHODS}

A total of 300 white shell hens' eggs representing 60 pooled samples (each sample is 5 eggs) of farms and baladi eggs (30 pooled samples of each) were collected from different poultry farms' supermarkets and farmers' houses from Assiut city and its surrounding villages, Egypt, from the period from January 2015 to August 2015. Eggs samples were collected in clean and sterile bag and transferred as son as possible to the laboratory for microbiological examination:-

A- Preparation of eggs samples for microbiological examination:

1- Egg shell was prepared by surface rinse method according to Moats (1980).

2- Egg content was evacuated for microbiological examination according to Speck (1976).
B- Preparation of serial dilution:

Ten fold serial dilutions was done from the rinse solution obtained from each group (five eggs) as well as ten fold serial dilution was done from the content of each group (five eggs) according to A.P.H.A. (2001).

C- Microbiological examination of the prepared egg shell solution as well as egg content by the flowing:-

1- Aerobic plate count according to A.P.H.A. (2001).

2- Enterococci count according to Deible and Hartman (1976).

3- Total yeasts and molds count according to Mislivec et al. (1992).

4- Total coliforms, faecal coliforms and E. coli count by MPN technique according to FAO (1992).

5- Isolation and identification of Staphylococcus aureus according to A.P.H.A. (2001).

6- Isolation and identification of Listeria monocytogenes according to Fiengold and Martin (1982).

7- Isolation and identification of Salmonella spp. according to Cox (1988).

The resulting data were analyzed using SPSS (2007) for Windows (SPSS, version 16, Inc., Chicago, IL). Chi-square test and t-test analysis were performed, differences were considered significant at values of $\mathrm{P}$ $<0.05$.

\section{RESULTS}

Table 1: Statistical analytical results of microbiological examination of farms and baladi hens' eggs shell.

\begin{tabular}{|c|c|c|c|c|c|c|c|c|c|c|}
\hline \multirow{3}{*}{$\begin{array}{c}\text { Microbial } \\
\text { examination }\end{array}$} & \multicolumn{5}{|c|}{ Farms eggs counts (cfu/shell) } & \multicolumn{5}{|c|}{ Baladi eggs counts (cfu/shell) } \\
\hline & \multicolumn{2}{|c|}{$\begin{array}{l}\text { Positive } \\
\text { samples }\end{array}$} & \multirow{2}{*}{ Min. } & \multirow{2}{*}{ Max. } & \multirow{2}{*}{ Average } & \multicolumn{2}{|c|}{$\begin{array}{l}\text { Positive } \\
\text { samples }\end{array}$} & \multirow{2}{*}{ Min. } & \multirow{2}{*}{ Max. } & \multirow{2}{*}{ Average } \\
\hline & No./30 & $\%$ & & & & No./30 & $\%$ & & & \\
\hline APC & 27 & $90^{\mathrm{a}}$ & $2.0 \times 10^{2}$ & $1.0 \times 10^{4}$ & $2.4 \times 10^{3 * *}$ & 30 & $100^{\mathrm{a}}$ & $1.6 \times 10^{3}$ & $7.5 \times 10^{5}$ & $1.1 \times 10^{5 * *}$ \\
\hline Enterococci & 11 & $36.7^{\mathrm{a}}$ & $1.0 \times 10^{2}$ & $2.0 \times 10^{3}$ & $3.6 \times 10^{2^{*}}$ & 24 & $80^{\mathrm{b}}$ & $1.0 \times 10^{2}$ & $1.5 \times 10^{5}$ & $1.2 \times 10^{4^{*}}$ \\
\hline $\begin{array}{l}\text { Yeasts \& } \\
\text { Molds }\end{array}$ & 19 & $63.3^{\mathrm{a}}$ & $1.0 \times 10^{2}$ & $1.0 \times 10^{3}$ & $4.0 \times 10^{2 *}$ & 23 & $76.7^{\mathrm{a}}$ & $1.8 \times 10^{2}$ & $1.0 \times 10^{6}$ & $4.7 \times 10^{4^{*}}$ \\
\hline
\end{tabular}

\footnotetext{
${ }^{a, b}$ Percentages in the same raw with different letters indicate having significance difference by using Chi-square test.

${ }^{* *}$ Indicates averages in the same raw having significance difference by using $t$ test.
} 
Table 2: Statistical analytical results of microbiological examination of farms and baladi hens' eggs content.

\begin{tabular}{|c|c|c|c|c|c|c|c|c|c|c|}
\hline \multirow{3}{*}{$\begin{array}{c}\text { Microbial } \\
\text { examination }\end{array}$} & \multicolumn{5}{|c|}{ Farms eggs counts (cfu/ml) } & \multicolumn{5}{|c|}{ Baladi eggs counts $(\mathrm{cfu} / \mathrm{ml})$} \\
\hline & \multicolumn{2}{|c|}{$\begin{array}{l}\text { Positive } \\
\text { samples }\end{array}$} & \multirow{2}{*}{ Min. } & \multirow{2}{*}{ Max. } & \multirow{2}{*}{ Average } & \multicolumn{2}{|c|}{ Positive samples } & \multirow{2}{*}{ Min. } & \multirow{2}{*}{ Max. } & \multirow{2}{*}{ Average } \\
\hline & No./30 & $\%$ & & & & No./30 & $\%$ & & & \\
\hline APC & 11 & $36.7^{\mathrm{a}}$ & $1.0 \times 10^{2}$ & $2.3 \times 10^{3}$ & $7.9 \times 10^{2 *}$ & 24 & $80^{\mathrm{b}}$ & $1.0 \times 10^{2}$ & $5.7 \times 10^{4}$ & $4.6 \times 10^{3 *}$ \\
\hline Enterococci & 4 & $13.3^{\mathrm{a}}$ & $2.0 \times 10^{2}$ & $1.1 \times 10^{3}$ & $5.8 \times 10^{2^{*}}$ & 3 & $10^{\mathrm{a}}$ & $1.0 \times 10^{2}$ & $9.0 \times 10^{2}$ & $5.0 \times 10^{2 *}$ \\
\hline $\begin{array}{c}\text { Yeasts \& } \\
\text { Molds }\end{array}$ & 8 & $26.7^{\mathrm{a}}$ & $1.0 \times 10^{2}$ & $5.0 \times 10^{2}$ & $3.0 \times 10^{2^{*}}$ & 11 & $36.7^{\mathrm{a}}$ & $1.0 \times 10^{2}$ & $1.0 \times 10^{5}$ & $9.2 \times 10^{3 *}$ \\
\hline
\end{tabular}

Table 3: Incidence of coliforms, faecal coliforms and E. coli recovered from farms and baladi hens' eggs shell using MPN/shell.

\begin{tabular}{ccccccc}
\hline \multirow{2}{*}{$\begin{array}{c}\text { Types of eggs } \\
\text { samples }\end{array}$} & \multicolumn{2}{c}{$\begin{array}{c}\text { Positive samples } \\
\text { recovered coliforms }\end{array}$} & $\begin{array}{c}\text { Positive samples recovered faecal } \\
\text { coliforms }\end{array}$ & Positive samples recovered \\
\cline { 2 - 7 } & No./30 & $\%$ & No./30 & $\%$ & Eoli \\
\hline Farms eggs & 3 & $10^{\mathrm{a}}$ & 2 & $6.7^{\mathrm{a}}$ & 2 & $6.7^{\mathrm{a}}$ \\
\hline Baladi eggs & 26 & $86.7^{\mathrm{b}}$ & 22 & $73.3^{\mathrm{b}}$ & 16 & $53.3^{\mathrm{b}}$ \\
\hline
\end{tabular}

${ }^{\mathrm{a}, \mathrm{b}}$ Percentages in the same column with different letters indicate having significance difference by using Chi-square test.

Table 4: Frequency distribution of positive eggs shells based on coliforms, faecal coliforms and E. coli count using MPN/shell.

\begin{tabular}{|c|c|c|c|c|c|c|c|c|c|c|c|c|}
\hline \multirow{3}{*}{ Range } & \multicolumn{6}{|c|}{ farms eggs samples (No./30) } & \multicolumn{6}{|c|}{ baladi eggs samples (No./30) } \\
\hline & \multicolumn{2}{|c|}{ Coliforms } & \multicolumn{2}{|c|}{$\begin{array}{c}\text { Faecal } \\
\text { coliforms }\end{array}$} & \multicolumn{2}{|c|}{ E. coli } & \multicolumn{2}{|c|}{ Coliforms } & \multicolumn{2}{|c|}{$\begin{array}{c}\text { Faecal } \\
\text { coliforms }\end{array}$} & \multicolumn{2}{|c|}{ E. coli } \\
\hline & No. & $\%$ & No. & $\%$ & No. & $\%$ & No. & $\%$ & No. & $\%$ & No. & $\%$ \\
\hline$<3^{*}$ & 27 & 90 & 28 & 93.3 & 28 & 93.3 & 4 & 13.3 & 8 & 26.7 & 14 & 46.7 \\
\hline $3-<10$ & 2 & 6.7 & 1 & 3.3 & 1 & 3.3 & 2 & 6.7 & 7 & 23.3 & 6 & 20 \\
\hline $10-<10^{2}$ & 0 & 0 & 0 & 0 & 0 & 0 & 7 & 23.3 & 8 & 26.7 & 5 & 16.7 \\
\hline $10^{2}-<10^{3}$ & 1 & 3.3 & 1 & 3.3 & 1 & 3.3 & 4 & 13.3 & 1 & 3.3 & 3 & 10 \\
\hline$\geq 10^{3}$ & 0 & 0 & 0 & 0 & 0 & 0 & 13 & 43.3 & 6 & 20 & 2 & 6.6 \\
\hline Total & 30 & 100 & 30 & 100 & 30 & 100 & 30 & 100 & 30 & 100 & 30 & 100 \\
\hline
\end{tabular}

$<3 *$ means negative results

Table 5: Incidence of coliforms, faecal coliforms and E. coli recovered from farms and baladi hens' eggs content using MPN/ml.

\begin{tabular}{ccccccc}
\hline \multirow{2}{*}{$\begin{array}{c}\text { Types of eggs } \\
\text { samples }\end{array}$} & \multicolumn{2}{c}{$\begin{array}{c}\text { Positive samples } \\
\text { recovered coliforms }\end{array}$} & $\begin{array}{c}\text { Positive samples recovered } \\
\text { faecal coliforms }\end{array}$ & \multicolumn{2}{c}{$\begin{array}{c}\text { Positive samples recovered } E . \\
\text { coli }\end{array}$} \\
\cline { 2 - 7 } & No./30 & $\%$ & No./30 & $\%$ & No./30 & $\%$ \\
\hline Farms eggs & 0 & 0 & 0 & 0 & 0 & 0 \\
\hline Baladi eggs & 6 & 20 & 3 & 10 & 2 & 6.7 \\
\hline
\end{tabular}


Table 6: Frequency distribution of positive eggs content based on coliforms, faecal coliforms and E. coli count using MPN/ml.

\begin{tabular}{|c|c|c|c|c|c|c|c|c|c|c|c|c|}
\hline \multirow{3}{*}{ Range } & \multicolumn{6}{|c|}{ farms eggs samples (No./30) } & \multicolumn{6}{|c|}{ baladi eggs samples (No./30) } \\
\hline & \multicolumn{2}{|c|}{ Coliforms } & \multicolumn{2}{|c|}{$\begin{array}{l}\text { Faecal } \\
\text { coliforms }\end{array}$} & \multicolumn{2}{|c|}{ E. coli } & \multicolumn{2}{|c|}{ Coliforms } & \multicolumn{2}{|c|}{$\begin{array}{l}\text { Faecal } \\
\text { coliforms }\end{array}$} & \multicolumn{2}{|c|}{ E. coli } \\
\hline & No. & $\%$ & No. & $\%$ & No. & $\%$ & No. & $\%$ & No. & $\%$ & No. & $\%$ \\
\hline$<3 *$ & 30 & 100 & 30 & 100 & 30 & 100 & 24 & 80 & 27 & 90 & 28 & 93.3 \\
\hline $3-<10$ & 0 & 0 & 0 & 0 & 0 & 0 & 2 & 6.7 & 1 & 3.3 & 1 & 3.3 \\
\hline $10-<10^{2}$ & 0 & 0 & 0 & 0 & 0 & 0 & 4 & 13.3 & 2 & 6.7 & 1 & 3.3 \\
\hline $10^{2}-<10^{3}$ & 0 & 0 & 0 & 0 & 0 & 0 & 0 & 0 & 0 & 0 & 0 & 0 \\
\hline$\geq 10^{3}$ & 0 & 0 & 0 & 0 & 0 & 0 & 0 & 0 & 0 & 0 & 0 & 0 \\
\hline Total & 30 & 100 & 30 & 100 & 30 & 100 & 30 & 100 & 30 & 100 & 30 & 100 \\
\hline \multicolumn{13}{|c|}{$\begin{array}{l}\text { Table 7: Incidence of Staph. aureus, CNS, Listeria monocytogens and Salmonella spp. on egg shell of farms and } \\
\text { baladi hens' eggs. }\end{array}$} \\
\hline \multirow{2}{*}{\multicolumn{2}{|c|}{ Microorganisms }} & \multicolumn{5}{|c|}{ Farms eggs } & \multicolumn{6}{|c|}{ Baladi eggs } \\
\hline & & \multicolumn{3}{|c|}{ No./30 } & \multicolumn{2}{|c|}{$\%$} & \multicolumn{3}{|c|}{ No./30 } & \multicolumn{3}{|c|}{$\%$} \\
\hline \multicolumn{3}{|c|}{ Staph. aureus } & 10 & & \multicolumn{2}{|c|}{33.3} & \multicolumn{3}{|c|}{12} & \multicolumn{3}{|c|}{40} \\
\hline \multicolumn{2}{|c|}{ CNS } & & 1 & & \multicolumn{2}{|c|}{3.3} & \multicolumn{3}{|c|}{14} & \multicolumn{3}{|c|}{46.7} \\
\hline \multicolumn{3}{|c|}{ Listeria monocytogens } & Nil & & \multicolumn{2}{|c|}{ Nil } & \multicolumn{3}{|c|}{1} & \multicolumn{3}{|c|}{3.3} \\
\hline \multicolumn{2}{|c|}{ Salmonella spp. } & \multicolumn{3}{|c|}{ Nil } & \multicolumn{2}{|c|}{ Nil } & \multicolumn{3}{|c|}{ Nil } & \multicolumn{3}{|c|}{ Nil } \\
\hline
\end{tabular}

CNS means coagulase negative Staphylococci

Table 8: Incidences of Staph. aureus, CNS, Listeria monocytogens and Salmonella spp. in egg content of farms and baladi hens' eggs

\begin{tabular}{ccccc}
\hline \multirow{2}{*}{ Microorganisms } & \multicolumn{2}{c}{ Farms eggs } & \multicolumn{2}{c}{ Baladi eggs } \\
\cline { 2 - 5 } & No./30 & $\%$ & No./30 & 13.3 \\
\hline Staph. aureus & 3 & 10 & 4 & 43.3 \\
\hline CNS & 4 & 13.3 & 13 & Nil \\
\hline Listeria monocytogens & Nil & Nil & Nil & Nil \\
\hline
\end{tabular}

CNS means coagulase negative Staphylococci

\section{DISCUSSION}

The illustrated results in Table 1 revealed that, the incidence of aerobic bacteria in the examined farms hens' eggs shell samples was $90 \%$ with a count ranged from $2.0 \times 10^{2}$ to $1.0 \times 10^{4}$ and with an average count of $2.4 \times 10^{3} \mathrm{cfu} /$ shell. Nearly similar incidence $(92 \%)$ but with higher average count $\left(4.52 \times 10^{5}\right.$ cfu/shell) were reported by El-Leboudy et al. (2011), while, lower incidences ( 80 and $58.82 \%$ ) with an averages count $\left(2.4 \times 10^{4}\right.$ and $8 \times 10^{3} \mathrm{cfu} /$ shell $)$ were reported by Abouzeid and Ashour (2002); El-Kholy et al. (2014), respectively. On the other hand, higher incidences $(100 \%)$ with averages count $\left(3.7 \times 10^{7}\right.$, $6.16 \times 10^{3}$ and $7.4 \times 10^{2} \mathrm{cfu} /$ shell) were estimated by Ahmed et al. (1985); El-Malt (2015); Wafy (2015), respectively. The incidence of aerobic bacteria in the examined baladi hens' eggs shell was $100 \%$ with a count ranged from $1.6 \times 10^{3}$ to $7.5 \times 10^{5}$ and with an 
average count of $1.1 \times 10^{5} \mathrm{cfu} /$ shell (Table 1). Lower incidences (80 and $97.1 \%$ ) but with nearly similar averages count of $\left(2.07 \times 10^{5}\right.$ and $\left.9.9 \times 10^{5} \mathrm{cfu} / \mathrm{shell}\right)$ were detected by Abouzeid and Ahour (2002); Refaat (2009), respectively.

The using of statistical analysis between the percentages of incidences of aerobic bacteria between farms and baladi hens' eggs shell by using SPSS program, the Pearson Chi-square test revealed that, there was no significance difference between the two types of eggs $(\chi 2=3.158$ and $\mathrm{P}>0.05)$. While, there was high significance difference in the average count/shell between farms and baladi hens' eggs by using $\mathrm{t}$-test $(\mathrm{t}=2.994$ and $\mathrm{P}<0.01)$. This findings indicated that, hens housed in cages (farms eggs) produce more eggs with higher quality and lesser bacterial contamination than hens housed in floors laying systems (baladi eggs). It is known that, eggs from caged birds are less likely to be contaminated with various microorganisms; this because the droppings fall through the cage floor doesn't come in contact with the eggs. Also, birds that are allowed to range outdoors are more likely to become contaminated from soil, insects, and rodents. Moreover, the concentration of dust accumulated in the floor housing system, contributes to higher contamination of eggs with bacteria compared to hens raised in the cage systems. Therefore, baladi eggs are more likely to be contaminated than eggs from farms. Moreover, isolation of the hens from faecal material in floor operation is essential to provide clean eggs with less bacterial contamination. Furthermore, high levels of external shell contamination can adversely affect the shelf life and food safety of eggs.

The external shell contamination could be important for the shelf life and the food safety of consumption eggs and egg products. It is hypothesized that, bacterial contamination of internal egg content could be the result of penetration of the shell by bacteria deposited on the surface of the egg after it has been laid (Smith et al., 2000).

The incidence of aerobic bacteria in farms hens' eggs content was $36.7 \%$ with a count ranged from $1.0 \times 10^{2}$ to $2.3 \times 10^{3}$ and with an average count of $7.9 \times 10^{2}$ $\mathrm{cfu} / \mathrm{ml}$ (Table 2). Higher incidences $(52,82.9,78,50$, 100 , and $100 \%$ ) with various averages count $\left(1.42 \times 10^{4}, 2.3 \times 10^{3}, 1.04 \times 10^{3}, 1.1 \times 10^{3}, 1.14 \times 10^{3}\right.$ and $1.5 \times 10 \mathrm{cfu} / \mathrm{ml})$ were estimated by Abouzeid and Ashour (2002); Refaat (2009); El-Leboudy et al. (2011); El-Kholy et al. (2014); El-Malt (2015); Wafy (2015), respectively. While, in baladi hens' eggs content; the incidence of aerobic bacteria was $80 \%$ with a count ranged from $1.0 \times 10^{2}$ to $5.7 \times 10^{4}$ and with an average count of $4.6 \times 10^{3} \mathrm{cfu} / \mathrm{ml}$ (Table 2). Lower incidences (76 and $68.6 \%$ ) with averages count of $2.68 \times 10^{4}$ and $2.3 \times 10^{3} \mathrm{cfu} / \mathrm{ml}$ were detected by Abouzeid and Ashour (2002); Refaat (2009), respectively.

The statistical analysis revealed that, there was high significance difference between incidence of aerobic bacteria of farms and baladi hens' eggs content by using Pearson Chi-square test $(\chi 2=11.589$ and $\mathrm{P}<$ $0.01)$. While, there was no significance difference between averages count of both types of eggs by using t-test $(\mathrm{t}=0.984$ and $\mathrm{P}>0.05)$. From the obtained results it is concluded that, the wide range of aerobic bacterial incidences between farms and baladi hens' eggs may be due to the variation in methods of production, handling and storage.

The results listed in Table 1 revealed that, the incidence of Enterococci in farms hens' eggs shell was $36.7 \%$ with a count ranged from $1.0 \times 10^{2}$ to $2.0 \times 10^{3}$ and with an average count of $3.6 \times 10^{2}$ $\mathrm{cfu} /$ shell. Lower incidences (11.4 and $4.4 \%$ ) with averages count of $\left(1.3 \times 10^{5}\right.$ and $\left.1.6 \times 10^{2} \mathrm{cfu} / \mathrm{shell}\right)$ were recorded by Refaat (2009); El-Malt (2015), respectively. On the other hand, higher incidences (64 and $72 \%$ ) with relatively higher averages count $\left(1.6 \times 10^{3}\right.$ and $1.33 \times 10^{3} \mathrm{cfu} /$ shell $)$ were reported by Ahmed et al. (1985); Abouzeid and Ashour (2002), respectively. Furthermore, the incidence of Enterococci in baladi hens' eggs shell was $80 \%$ with a count ranged from $1.0 \times 10^{2}$ to $1.5 \times 10^{5}$ and with an average count of $1.2 \times 10^{4} \mathrm{cfu} / \mathrm{shell}$ (Table 1). Lower incidence $(17.1 \%)$ with higher average count $\left(1.6 \times 10^{5} \mathrm{cfu} / \mathrm{shell}\right)$ was detected by Refaat (2009). In contrary, higher incidence $(100 \%)$ with higher average count $\left(8.05 \times 10^{5} \mathrm{cfu} / \mathrm{shell}\right)$ was found by Abouzeid and Ashour (2002).

Results of the statistical analysis revealed that, there was highly significance difference between incidences of Enterococci in farms and baladi hens' eggs shell by using Pearson Chi-square test $\left(\chi^{2}=\right.$ 11.589 and $\mathrm{P}<0.01)$. In contrast, there was no significance difference between averages count of both types of eggs by using t-test $(\mathrm{t}=1.276$ and $\mathrm{P}>$ 0.05).

The incidence of Enterococci in farms hens' eggs content was $13.3 \%$ with a count ranged from $2.0 \times 10^{2}$ to $1.1 \times 10^{3}$ and with an average count of $5.8 \times 10^{2}$ $\mathrm{cfu} / \mathrm{ml}$ (Table 2). Lower incidences (2.66 and 5.7\%) with various averages count $\left(1.25 \times 10^{5}\right.$ and $2.0 \times 10^{2}$ $\mathrm{cfu} / \mathrm{ml}$ ) were estimated by El-Leboudy and ElMossalami (2006); Refaat (2009), respectively. While, for baladi hens' eggs content, the incidence of Enterococci was $10 \%$ with a count ranged from $1.0 \times 10^{2}$ to $9.0 \times 10^{2}$ and with an average count of $5.0 \times 10^{2} \mathrm{cfu} / \mathrm{ml}$ (Table 2). Lower incidences (6 and $8.6 \%$ ) with averages count of $1.12 \times 10^{5}$ and $2.3 \times 10^{2}$ $\mathrm{cfu} / \mathrm{ml}$ were obtained by El-Leboudy and ElMossalami (2006); Refaat (2009), respectively. On 
the other hand, higher incidence (84\%) with an average count of $6.5 \times 10^{3} \mathrm{cfu} / \mathrm{ml}$ was recorded by Abouzeid and Ashour (2002). Statistical analysis revealed that, there was no significance difference between incidences of Enterococci in farms and baladi hens' eggs content by using Pearson Chisquare test $(\chi 2=0.162$ and $\mathrm{P}>0.05)$. Also, t-test showed no significance difference between the averages count of both types eggs $(t=0.254$ and $\mathrm{P}>$ $0.05)$.

The presence of Enterococcus faecalis in food is linked with a wide variety of human infections such as endocarditis, urinary and genital tract infections, meningitis and septicemia (Mannu et al., 2003) and the high contamination of eggs by Enterococci in this study indicated that, eggs may represent a hazard for human being by accidental contamination of eggs based products by Enterococci during food preparation. Therefore, hygienic quality of eggs is very important to safeguard human from infection.

The incidence of yeasts and molds in farms hens' eggs shell was $63.3 \%$ with a count ranged from $1.0 \times 10^{2}$ to $1.0 \times 10^{3}$ and with an average count of $4.0 \times 10^{2} \mathrm{cfu} /$ shell (Table 1). Nearly similar incidence (65\%) was found by Salihu et al. (2015) and also, similar average count of $2.7 \times 10^{4} \mathrm{cfu} / \mathrm{shell}$ was detected by Salem et al. (2009). While, lower incidences (53 and $44.12 \%$ ) with averages count of $1.31 \times 10^{3}$ and $5.9 \times 10^{2} \mathrm{cfu} /$ shell were estimated by ElLeboudy et al. (2011); El-Kholy et al. (2014), respectively. In contrary, higher incidences (94.3 and $66.6 \%)$ with averages count of $1.5 \times 10^{4}$ and $2.5 \times 10^{2}$ $\mathrm{cfu} / / \mathrm{shell}$ were recovered by Refaat (2009); El-Malt (2015), respectively. For baladi hens' eggs shell, the incidence of yeasts and molds was $76.7 \%$ with a count ranged from $1.8 \times 10^{2}$ to $1.0 \times 10^{6}$ and with an average count of $4.7 \times 10^{4} \mathrm{cfu} / \mathrm{shell}$ (Table 1). Higher incidence $(94.3 \%)$ with nearly similar an average count of $2.5 \times 10^{5} \mathrm{cfu} / \mathrm{shell}$ was recorded by Refaat (2009).

The statistical analysis revealed that, there was no significance difference between incidences of yeasts and molds in farms and baladi hens' eggs shell by using Pearson Chi-square test $(\chi 2=1.270$ and $\mathrm{P}>$ $0.05)$. Also, t-test showed no significance difference between averages count of both types eggs $(t=0.976$ and $\mathrm{P}>0.05)$. In spite of statistical analysis results, the relatively higher incidences and count of yeasts and molds in baladi hens' eggs shell than that of farms eggs obtained in this study may attributed to that, the breeding system of hens in farms' houses where birds come in contact with the ground, spoiled food materials and animal faeces may give a chance to fungal contamination of eggs shell.

Concerning yeasts and molds in farms hens' eggs content, the incidence was $26.7 \%$ with count ranged from $1.0 \times 10^{2}$ to $5.0 \times 10^{2}$ and an average count of $3.0 \times 10^{2} \mathrm{cfu} / \mathrm{ml}$ (Table 2). Lower incidence $(23.53 \%)$ with nearly similar average count of $2.6 \times 10^{2} \mathrm{cfu} / \mathrm{ml}$ was found by El-Kholy et al. (2014). While, higher incidences $(38,85.7,29$ and $46.6 \%)$ with various averages counts of $3.4 \times 10^{3}, 4.2 \times 10,4.0 \times 10^{2}$ and $5.14 \times 10 \mathrm{cfu} / \mathrm{ml}$ were estimated by Neamatallah et al. (2009); Refaat (2009); El-Leboudy et al. (2011); ElMalt (2015), respectively. On the other hand, the incidence of yeats and molds in baladi hens' eggs content was $36.7 \%$ with count ranged from $1.0 \times 10^{2}$ to $1.0 \times 10^{5}$ and with an average count of $9.2 \times 10^{3}$ $\mathrm{cfu} / \mathrm{ml}$ (Table 2). Higher incidence $(71.4 \%)$ but with lower average count $(3.8 \times 10 \mathrm{cfu} / \mathrm{ml})$ was recorded by Refaat (2009). The results of statistical analysis revealed that, there was no significance difference between incidences of yeasts and molds in farms and baladi hens' eggs content by using Pearson Chisquare test $(\chi 2=0.693$ and $\mathrm{P}>0.05)$. Also, t-test showed no significance difference between averages count of both types eggs $(t=0.834$ and $\mathrm{P}>0.05)$.

From the public health point of view, certain strains of molds were implicated in food poisoning outbreaks due to production of aflatoxins, as well as, some strains of molds are capable of forming toxins that cause mycotoxicosis in man and neoplastic diseases including leukemia and other cancers among consumers (Bullerman, 1980).

The recorded results in Tables $3 \& 4$ revealed that, $10 \%$ of farms hens' eggs shell had coliforms organisms with highest frequency distribution of $6.7 \%$ and laid in the range of $3-<10 \mathrm{cfu} / \mathrm{shell}$. Higher results of $64,33.3,37.1,30$ and $47.06 \%$ were estimated by Ahmed et al. (1985); El-Leboudy and El-Mossalami (2006); Refaat (2009); El-Leboudy et al. (2011); El-Kholy et al. (2014), respectively. For baladi hens' eggs shell, the incidence of coliforms was $86.7 \%$ with highest frequency distribution of $43.3 \%$ and laid in the range of $\geq 10^{3} \mathrm{cfu} /$ shell (Table 3 \& 4). Lower incidences of 69.3 and $51.4 \%$ were detected by El-Leboudy and El-Mossalami (2006); Refaat (2009), respectively. The Pearson Chi-square result revealed that, there was higher significance differences between the incidences of coliforms organisms in farms and baladi hens' eggs shell $(\chi 2=$ 35.306 and $\mathrm{P}<0.01)$. These results go parallel with Jones et al. (2011) as the authors revealed that, shell contamination by coliforms was greater in free-range floor system than of conventional cage eggs. Furthermore, coliforms organisms couldn't be detected in farms hens' eggs content in this study (Table 4), while, the incidence of coliforms in baladi hens' eggs content was $20 \%$ (Table 5) with highest frequency distribution of $13.3 \%$ and laid in the rage of $10-<10^{2} \mathrm{cfu} / \mathrm{ml}$ (Table 6). Higher incidence of $58.66 \%$ was found by El-Leboudy and El-Mossalami (2006), while, Refaat (2009) couldn't find coliforms organisms in baladi hens' eggs content. From the obtained results, it is concluded that, higher 
superiority of farms hens' eggs than baladi hens' eggs based on incidence of coliforms organisms; this may be attributed to the good hygienic measures that applied in poultry farms.

Concerning faecal coliforms, the incidence in farms hens' eggs shell was $6.7 \%$ (Table 3) with highest frequency distribution of $3.3 \%$ and laid in the range of $3-<10$ and $10^{2}-<10^{3}$ (Table 4). Higher incidences of 11.4 and $20.59 \%$ were estimated by Refaat (2009); El-Kholy et al. (2014), respectively. In baladi hens' eggs shell, the incidence of faecal coliforms was $73.3 \%$ with highest frequency distribution of $26.7 \%$ and laid in the range of 10 - < $10^{2} \mathrm{cfu} /$ shell (Tables $3 \& 4$ ). Lower incidence of $22.9 \%$ was obtained by Refaat (2009). In regard to Pearson Chi-square test, there was higher significance difference between incidences of faecal coliforms in farms and baladi hens' eggs shell $\left(\chi^{2}=\right.$ 27.778 and $\mathrm{P}<0.01)$. Faecal coliforms couldn't be detected in farms hens' eggs content in this study, while, in baladi eggs the incidence was $10 \%$ with highest frequency distribution of $6.7 \%$ and laid in the range of $10-<10^{2} \mathrm{cfu} / \mathrm{ml}$ (Tables $5 \& 6$ ). Detection of faecal coliforms in eggs content at this study; give an indication to presence of some intestinal pathogens which may lead to foodborn infection and intoxication.

The results recorded in Tables 1, 2, 3 and 5 revealed that, the incidence of Enterococci in farms hens' eggs was more than that of coiforms and faecal coliforms. This may be attributed to the higher resistance of Enterococci to environmental conditions than faecal coliforms (Bordalo et al., 2002) or due to other factors which need further investigations.

The results tabulated in Tables $3 \& 4$ revealed that, E. coli was isolated from farms hens' eggs shell in incidence of $6.7 \%$ with highest frequency distribution of $16.7 \%$ and laid in the range of $10-<$ $10^{2} \mathrm{cfu} / \mathrm{shell}$. Nearly similar result $6.1 \%$ was detected by Mahdavi et al. (2012), while, lower incidence of 4\% was found by Al-Ashmawy (2013). In contrast, higher incidences of 48, 48.89, 28.3, 14.71, 27.5 and $26.67 \%$ were reported by Ahmed et al. (1985); Bastawrows et al. (1997); Adesiyun et al. (2005); El-Kholy et al. (2014); Ibrahim et al. (2014); Fardows and Shamsuzzaman (2015), respectively. For baladi hens' eggs shell, the incidence of $E$. coli was $53.3 \%$ with highest frequency distribution of $20 \%$ and laid in the range of $3-<10 \mathrm{cfu} / \mathrm{shell}$ (Tables $3 \& 4$ ). Lower incidences of 32 and $44 \%$ were revealed by Al-Ashmawy (2013); Ibrahim et al. (2014), respectively. Concerning to Pearson Chisquare test, there was higher significance difference between incidences of $E$. coli in farms and baladi hens' eggs shell $(\chi 2=15.556$ and $\mathrm{P}<0.01)$.
The farms hens' eggs content were negative for $E$. coli isolation (Table 5) and this result coincided with Refaat (2009); Al-Ashmawy (2013); El-Malt (2015) as the authors failed to isolate $E$. coli from farms hens' eggs content. While, for baladi hens' eggs content, the incidence of $E$. coli was $6.7 \%$ with frequency distribution of $3.3 \%$ and laid in the ranges of $3-<10$ and $10-<10^{2} \mathrm{cfu} / \mathrm{ml}$ (Tables $5 \& 6$ ). Higher incidences of 23 and 19\% were found by AlAshmawy (2013); Ibrahim et al. (2014), respectively. Moreover, E. coli is a known causative agent of diarrhea and other food-borne related illnesses through the ingestion of contaminated foodstuffs; and also, presence of E. coli in eggs is a good indicator to faecal pollution of eggs and the possibility to presence of some enteric pathogens which constitute public health hazards to consumers. From the obtained results in this study; it is concluded that, farms hens' eggs have better hygienic measures during production and handling than baladi hens' eggs.

The tabulated results in Table 7 showed the pathogenic microorganisms that having public health significance isolated from farms and baladi hens' eggs shell. The incidence of Staph. aureus in farms hens' eggs shell was $33.3 \%$ and this result coincided with El-Malt (2015); while, higher incidences of 80, 84 and $82 \%$ were estimated by Ahmed et al. (1985); Abouzeid and Ashour (2002); El-Leboudy et al. (2011), respectively. In baladi hens' eggs shell, the incidence of Staph. aureu was 40\% (Table 7). Higher incidence of $96 \%$ was reported by Abouzeid and Ashour (2002). Moreover, the incidence of Staph. aureus in farms hens' eggs content was $10 \%$ (Table 8). Lower incidence of $2.9 \%$ was found by Refaat (2009); while, higher incidences of 56 and $20 \%$ were estimated by Abouzeid and Ashour (2002); El-Malt (2015), respectively. The baladi hens' eggs content revealed that, the incidence of Staph. aureus was $13.3 \%$ (Table 8) and this result lower than that detected by Abouzeid and Ashour (2002) and Rfaat (2009) as they revealed incidences of 88 and $17.1 \%$, respectively.

The public health significance of Staph. aureus is ranged from a variety of self-limiting to lifethreatening diseases. The bacteria are a leading cause of food poisoning, resulting from the consumption of food contaminated with enterotoxins which is characterized by rapid onset of nausea, vomiting, abdominal pain, cramps, and diarrhea. Scalded skin syndrome is caused by exfoliative toxins secreted on the epidermis and mostly affects neonates and young children. Other skin conditions caused by Staphylococcal exfoliative toxins include blisters, skin loss, pimples, furuncles, impetigo, folliculitis, abscesses, poor temperature control, fluid loss, and secondary infection (Le Loir et al., 2003; Murray 
et al., 2003; Fridkin et al., 2005 and Eisenstein, 2008).

The coagulase negative Staphylococci (CNS) was isolated from farms hens' eggs shell in a percentage of $3.3 \%$ (Table 7) and this result lower than that estimated by El-Malt (2015) where the author found incidence of $15.55 \%$. Concerning Baladi hens' eggs shell, the incidence of CNS was $46.7 \%$ (Table 7). Moreover, the incidences of CNS in farms and baladi hens' eggs content were 13.3 and $43.3 \%$, respectively (Table 8). El-Malt (2015) showed lower incidence of $8.9 \%$ in farms hens' eggs content. From the public health point of view, coagulase negative staphylococci have been identified as the etiological agent in various infections and are among the microorganisms most frequently isolated in nosocomial infections (Cunha et al., 2006). Also, CNS have been implicated in infective endocarditis (Patel et al., 2000), prosthetic joint infections (Trampuz and Zimmerli, 2005), neonatal septiceamia (Ghelbi et al., 2008), Enterotoxins production (Veras et al., 2008) and bacterial eye infections (Ogbolu et al., 2011).

The incidence of Listeria monocytogenes in baladi hens' eggs shell in this study was 3.3\% (Table 7) and this result lower than that reported by Abouzeid and Ashour (2002) as they found incidence of $32 \%$. The shell and content of farms hens' eggs and content of baladi hens' eggs were negative for Listeria monocytogenes in this study (Tables $7 \& 8$ ). Several authors failed to detect Listeria monocytogenes in shell and in content farms hens' eggs, as Adesiyun et al. (2005); Korashy et al. (2008); Mahdavi et al. (2012). On the other hand, Saad and El-Prince (1995); Abouzeid an Ashour (2002); Sayed et al. (2009); El-Malt (2015) detected Listeria monocytogenes in farms hens' eggs in percentage of 17.78, 20, 7 and $2.2 \%$ for the mentioned authors respectively. Moreover, the low incidence of Listeria monocytogens in this study may be attributed to source of eggs, time of sampling or other factors which need further investigations.

The public health effects listeriosis in human include septicemia, meningitis or meningoencephalitis, encephalitis, corneal ulcer, pneumonia, and intrauterine or cervical infection in pregnant women, which may result in spontaneous abortion (second to third trimester) or stillbirth (Gray and Killinger, 1966; Holland et al., 1987; Whitelock-Jones et al., 1989 and Armstrong and Fung, 1993).

Concerning Salmonella spp., the microorganism couldn't be isolated from the shell and content of both types of eggs (Tables $7 \& 8$ ). This result coincided with Hassan (1995); Abouzeid and Ashour (2002); El-Leboudy et al. (2011); Mahdavi et al. (2012); Folorunsho and Charles (2013); Al-Iedani et al. (2014); El-Kholy et al. (2014); El-Malt (2015).
The failure of Salmonella spp. isolation in this study may be due to competition effect of aerobic contaminant or using of antibiotic as growth promoting and/or for treatment might inhibit Salmonella isolation or due to other factors which need further investigations.

This study revealed that, baladi hens' eggs have higher microbial load than farms hens' eggs. There are higher incidences of coliforms, faecal coliforms and $E$. coli organisms in baladi hens' eggs than those from farms hens' eggs. Eggs may be a source to same human pathogens specially Staphylococcus aureus and Listeria monocytogenes. Therefore, hygienic measures should be applied in home produced hen for lower bacterial load in egg shell and subsequently in egg content and also, strict hygienic measures to safeguard egg consumes from being infected as well as to safe eggs from being deteriorated should be adopted in the farms. Thorough cooking and preparation of eggs and eggs containing food should be applied to safeguard human being from being infected with pathogenic organisms.

\section{REFERENCES}

A.P.H.A. (2001): Compendium of Methods for the Microbiological Examination of Foods. $4^{\text {th }}$ ed. American Public Heath Association, Washington, DC USA.

Abouzeid, A.M. and Ashour, Deena, A. (2002): Microbial contamination of hen's eggs. J. Egypt. Vet. Med. Assoc., 62 (60): 157-164.

Adesiyun, A.; Offiah, N.; Seepersadsingh, N.; Rodeigo, S.; Lashley, A.; Musai, L. and Georges, K. (2005): Microbial health risk posed by table eggs in Trinidad. Epidemiol. Infect., 133: 1049-1056.

Ahmed, A-H.A.; Moustafa, K.M.; Aboul-Khier, F. and El-Bassiony, T.A. (1985): Bacterial contamination of egg shells. Assiut Vet. Med. J., 14 (27): 123-127.

Al-Ashmawy, Maha, A.M. (2013): Prevalence of enterobacteriaceae in table eggs with particular reference to enterovirulent Escherichia coli strains. Int. J. Poultry Sci., 12 (7): 430-435.

Al-Iedani, A.A.; Khudor, M.H. and Oufi, N.M. (2014): Isolation and identification of Salmonella spp. from poultry farms by using different techniques and evaluation of their antimicrobial susceptibilities. Basra J. Vet. Res., 1 (1): 246-259.

Armstrong, R.W. and Fung, P.C. (1993): Brainstem encephalitis (Rhombencephalitis) due to Listeria monocytogenes: case report and review. Clin. Infect. Dis., 16 (5): 689-702. doi:10.1093/clind/16.5.689. PMID 8507761.

Bastawrows, A.F.; Khalil, Nawal, G.; Seedek, S.R. and Aly, Seham, M. (1997): Bacteriological studies on enterobacteriaceae isolated from 
table eggs in Assiut. Assiut Vet. Med. J., 36 (72): 203-213.

Bordalo, A.A.; Onrassami, $R$. and Dechsakolwatana, C. (2002): Survival of faecal indicator bacteria in tropical estuarine waters (Bangpakong River, Thailand). J. Appl. Microbiol., 93: 864871.

Bruce, J. and Drysdale, E.M. (1994): Trans-shell transmission. In Microbiology of the avian egg (ed. Board R. G. and R. Fuller). London: Chapman \& Hall, pp. 63-91.

Bullerman, L.B. (1980): Incidence of mycotoxic molds in domestic and imported cheeses. J. Food Safety. 2(1): 47-58. Dairy Sci. Abst. 42,7270 (1980).

Cox, N.A. (1988): Salmonella methodology update. Poultry Sci., 67 (6): 921-927.

Cunha, M.L.R.; Rugolo, L.M.R. and Lopes, C.A.M. (2006): Study of virulence factors in Coagulase Negative Staphylococcus isolates from newborns. Memorias do Instituto Oswaldo Cruz, 101 (6): 661-668.

Deible, R.H. and Hartman, P.A. (1976): The Enterococci. In: Compendium of Methods for Microbiological Examination of Foods. M.L. Speck (Ed.). $2^{\text {nd }}$ ed., American Public Heath Association, Inc.

Ebubekir, A.; Ahmet, S. and Ekerog, L. (2008): Effect of egg shape index on mechanical properties of chicken eggs. J. Food Eng., 85: 606-612.

Eisenstein, B.I. (2008): Treatment challenges in the management of complicated skin and softtissue infections. Clinical Microbiol. Infection, The Official Publication of the European Society of Clinical Microbiology and Infectious Diseases, 14 Suppl 2, 17-25. doi:10.1111/j.1469-0691.2008.01922.x

El-Kholy, A.M.; Hassan, G.M. and Ahmed, Dalia, M. (2014): Microbiological quality of poultry farm table eggs in Beni-Suef city, Egypt. Assiut Vet. Med. J., 60 (142): 10-13.

El-Leboudy, Ahlam, A. and El-Mossalami, Hanaa, $H$. (2006): Microbiological evaluation of table eggs with special reference to enteric pathogens in Alexandria governorate. J. Egypt. Vet. Med. Assoc., 66 (1): 141-153.

El-Leboudy, Ahlam, A.; El-Shenawy, N. and ElDayash, M. (2011): Criteria for evaluation of egg and egg products. Alexandria J. Vet. Sci., 34 (1): 77-88.

Ellen, H.H.; Bottcher, R.W.; Von Wachebfelt, E. and Takai, H. (2000): Dust levels and control methods in poultry houses. J. Agri. Safety Health, 6: 275-282.

El-Malt, Laila, M. (2015): Assessment of the microbial quality and aflatoxins content in poultry farms eggs sold in Qena city- upper Egypt. Assiut Vet. Med. J., 61 (145): 144-151.

FAO "Food and Agriculture Organisation" (1992): Manual of Food Quality Control. 4. Rev. 1.
Microbiological analysis. Food and Agriculture Organization of the United Nation. Rome, Italy.

Fardows, J. and Shamsuzzaman, S.M. (2015): A search for identifying aerobic bacteria by culture and multiplex PCR in market eggs causing gastroenteritis and enteric fever in Bangladesh. Annals Clin. Med. Microbiol., 1(1): 1001-107.

Finegold, S.M. and Martin, W.J. (1982): Bailey and Scott Diagnostic Microbiology. 6th Ed., C.V. Mosby Co. St. Louis, Toronto, London.

Folorunsho, O. and Charles, A. (2013): Effect of rinses on microbial quality of commercially available eggs and its components before processing from Ilorin in western Nigeria. Bitlis Eren. Univ. J. Sci. Technol., 3 (2): 4447.

Fridkin, S.K.; Hageman, J.C.; Morrison, M.; Sanza, L.T.; Como-Sabetti, K.; Jernigan, J.A.; Harriman, K.; Harrison, L.H.; Lynfield, R. and Farley, M.M. (2005): Methicillin-resistant Staphylococcus aureus disease in three communities. The New England J. Medicine, 352 (14): 1436.

Ghelbi, S.; Fakuor, Z.; Karamayar, M.; Khashabi, J.; Knanizadih, B.; Asghari-Sana, F.; Mahoodzadeh, H. and Majilesi, A.H. (2008): Coagulase Negative Staphylococcus: The most common cause of neonatal septiceamia in Urmia, Iran. Iran J. Pediatrics, 18 (3): 237-243.

Gray, M.L. and Killinger, A.H. (1966): Listeria monocytogenes and listeric infection. Bacteriol. Rev., 30: 309-382.

Hassan, S.A.A. (1995): Microbial evaluation of table eggs. M.V.Sc. Thesis, Fac. Vet. Med., Zagazig Univ., Egypt.

Heranz, S.; Moraneo, B. and Marazuela, M.D. (2007): Development of new pretreatment procedure for determination of fluoroquinolone residues in table egg. J. Chromatog. A., 1140 (1-2): 63-70.

Holland, S.; Alfonso, E.; Heidegger, D.; Mendelsohn, A.; Ullman, S. and Miller, D. (1987): Corneal ulcer due to Listeria monocytogenes. Cornea, 6 (2): 144-146.

Ibrahim, Jehan, I.; Mansour, Dali, H. and AbdelRahman, H.A. (2014): Prevalence and inhibition of microbial load on chicken eggs with special references to egg quality and hatchability. Am. J. Animal Vet. Sci., 9 (4): 294-302.

Jones, D.R.; Anderson, K.E. and Musgrove, M.T. (2011): Comparison of environmental and egg microbiology associated with conventional and free-rage laying hen management. Poultry Sci., 90: 2063-2068.

Korashy, Eiman; Wahba, Nahed, M. and Hassanein, $R$. (2008): Public health hazards of some bacterial pathogens associated with 
consumption of eggs and studying the best cooking methods for their destruction. Assiut Vet. Med. J., 54 (117): 59-77.

Le Loir, Y.; Baron, F. and Gautier, M. (2003): Staphylococcus aureus and food poisoning. Genetics Molecular Rese., 2 (1): 63-76.

Mahdavi, M.; Jalali, M.; Safaei, H. and Shamloo, E. (2012): Microbial quality and prevalence of Salmonella and Listeria in eggs. Int. J. Envi. Health Eng., 1 (6): 16-20.

Mannu, L.; Paba, E.; Daga, R.; Comunian, R.; Zanetti, S.; Dupre, I. and Sechi, L. (2003): Comparison of the incidence of virulence determinants and antibiotic resistance between Enterococcus faecium strains of dairy, animal and clinical origin. Int. J. Food Microbiol., 88: 291-304.

Mislivec, P.B.; Beuchat, L.R. and Cousin, M.A. (1992): Yeasts and molds. Chapter 16. Compendium of Methods for Microbiological Examination of Food. Vanderzant, C. and Splitoesser, D. (Eds.). $3^{\text {rd }}$ ed., American Public Health Association, Washington, DC, USA.

Moats, W.A. (1980): Classification of bacteria from commercial egg washers and washed and unwashed eggs. Appl. Environ. Microbiol., 40 (4): 710-714.

Murray, P.R.; Baron, E.J.; Jorgensen, J.H.; Landry, M.L.; Pfaller, M.A. and Yolken, R.H. (2003): Manual of Clinical Microbiology (8th ed.). Herdon, VA, United States of America: American Society for Microbiology.

Neamatallah, A.A.; El-Leboudy, Ahlam, A.; Amer, A.A. and El-Shenawy, Noha, M. (2009): Biosafety against fungal contamination of hen's eggs and mycotoxins producing species. Meteorology Env. Arid Land Agric. Sci., 20 (2): 63-73.

Ogbolu, D.O.; Terry Alli, O.A.; Ephraim, I.E.; Olaboyi, F.A. and Daini, O.A. (2011): In-vitro efficacy of antimicrobial agents used in the treatment of bacterial eye infections in Ibadan, Nigeria. African J. Clinical Experimental Microbiol., 12 (3): 124-127.

Patel, R.; Piper, K.E.; Rouse, M.S.; Uhi, R.J.; Cockerill, F.R. and Steckelberg, J.M. (2000): Frequency of isolation of Staphylococcus lugdunensis among staphylococcal isolates causing endocorditis: A 20 years experience. American Society Microbiol., 38 (11): 42624263.

Refaat, B.M. (2009): Microbiological evaluation of commercial hens and ducks eggs in Assiut governorate. M.V.Sc. Thesis, Fac. Vet. Med., Assiut Univ., Egypt.

S.P.S.S. "Statistical Package for Social Sciences" (2007): SPSS, version 16, Inc., Chicago, IL).
Saad, Nagah M. and El-Prince, Enas (1995): Prevalence of Listeria species in hen's eggs sold in Assiut city. Assiut Vet. Med. J., 33 (65): 127-131.

Salem, R.M.; El-Kaseh, R.M. and El-Diasty, Eiman, $M$. (2009): A study on the fungal contamination and prevalence of Aflatoxins and some antibiotic residues in table eggs. Arab J. Biotech., 12 (1): 65-72.

Salihu, M.D.; Garba, B. and Isah, Y. (2015): Evaluation of microbial contents of table eggs at retail outlets in Sokoto metropolis, Nigeria. Sokoto J. Vet. Sci., 13 (1): 22-28.

Sayed, M.; Abdel-Azeem, M.; Farghaly, M. and Hassanein, R. (2009): Using of PCR assay for identification of Listeria monocytogenes recovered from table eggs. Vet. World, 2 (12): 453-455.

Schoeni, J.L.; Glass, K.A.; Mcdermott, J.L. and Wong, A.C.L. (1995): Growth and penetration of Salmonella enteritidis, Salmonella heidelberg and Salmonella typhimurium in eggs. Intl. J. Food Microbiol., 24: 385-396.

Smith, A.; Rose, S.P.; Wells, R.G. and Pirgozliev, V. (2000): The effect of changing the excreta moisture of caged laying hens on the excreta and the microbial contamination of their egg shells. British Poultry Sci., 41: 168-173.

Speck, M.L. (1976): Compendium of Methods for Microbiological Examination of Foods. American Public Health Association. Washington D.C.

Theron, H.; Enter, P.V. and Lues, J.F.R. (2003): Bacterial growth on chicken eggs in various storage environments. Food Res. Int., 36: 969975.

Trampuz, A. and Zimmerli, W. (2005): Prosthetic Joint Infections: Update in diagnosis and treatment. Swiss Medical Weekly, 135: 243251.

Veras, J.; De Carmo, L.S.; Tong, L.C.; Shupp, J.W.; Cummings, C.; Dos Santos, D.A.; Cerqueira, M.M.; Cantini, A.; Nicoli, J.R. and Jett, M. (2008): A study of the enterotoxigenicity of coagulase-negative and coagulase-positive staphylococcal isolates from food poisoning outbreaks in Minas Gerais, Brasil. Int. J. Infectious Diseases, 12: 410-415.

Wafy, Y.S. (2015): A comparative study between organic and conventional table eggs. Assiut Vet. Med. J., 61 (145): 275-279.

Whitelock-Jones, L.; Carswell, J. and Rassmussen, K.C. (1989): Listeria pneumonia. A case report. South African Medical J., 75 (4): 188189. 


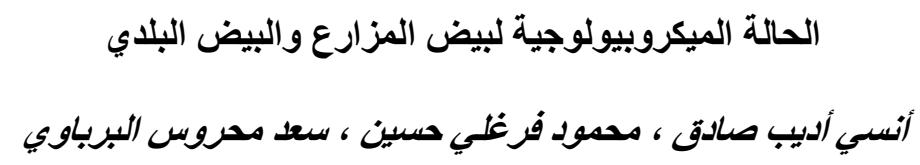

Email: onsi_2000@yahoo.com

Assiut University web-site: $\underline{\text { www.aun.edu.eg }}$

أُجريت هذه الدر اسة لمعرفة الحالة الميكروبيولوجية لبيض المزارع و البيض البلدي وكذللك عزل بعض البكتريـا الممرضـة التي تؤثر



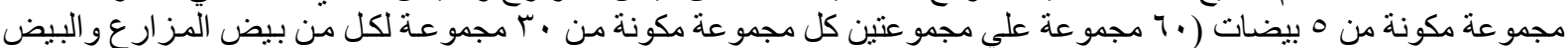

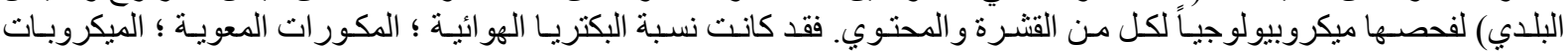

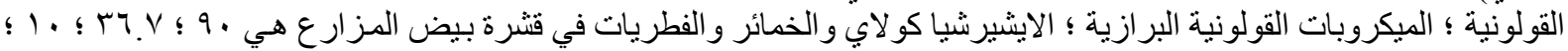

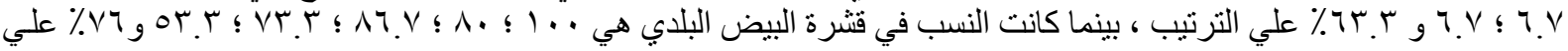



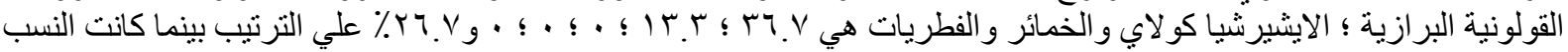

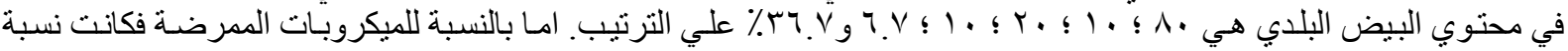

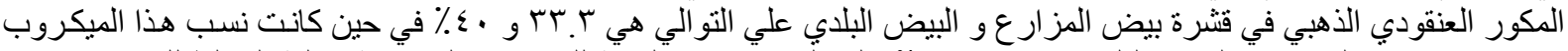

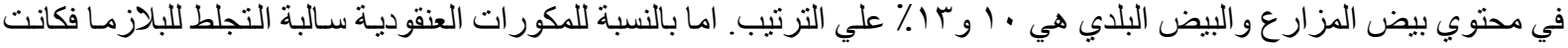

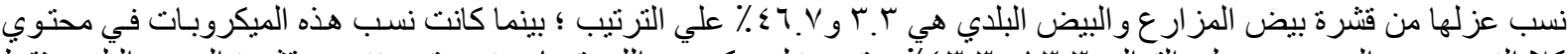

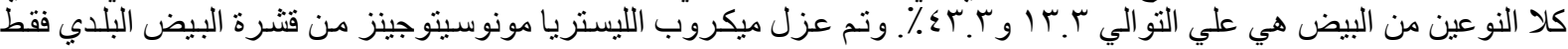

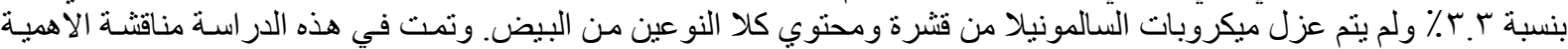

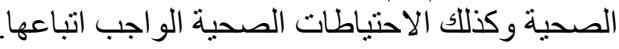

